\title{
COMPROMISE AND CONFLICT: THE TOBACCO WORKERS OF MEXICO CITY AND THE COLONIAL STATE, 1770-1810
}

I would like to begin this paper with two observations. The first concerns interpretations of the relations between the colonial state and labor. The second relates more specifically to the underlying assumptions of labor history. In recent years, a renewed interest in the relationship between state and society has emerged among historians in general, and of Latin America in particular, who have called for a closer examination of conflict and interaction between the state and various sectors of society, with an emphasis upon moving away from reductionist or reification interpretations of the state ${ }^{1}$. William Taylor's discussion of the role of the colonial state in people' lives provides an example of a more nuanced argument in which he argues that:

the state, by both its strengths and weaknesses, was a major force in the lives of the early Latin Americans, but it was not altogether an independent force, while capitalism, other economic structures, and the state conditioned social life, they did not simply determine it.

The reciprocal (which is not to say equal) connections... dopended on local responses and conditions - not just relentless pressure of external developments and authority... ${ }^{2}$.

1 See for example, Bright, Charles and Harding, Susan: «Processes of Statemaking and Popular Protest - An Introduction, in Statemaking and Social Movements - Essays in History and Theory, Charles Bright and Susan Harding, eds., Ann Arbor, Michigan, 1984, pags. 3.5; Evans, Peter, et al.: Bringing the Stale Back In, Cambridge, 1986. Coatstiorth, John H.: "The Limits of Colonial Absolutism: The State in Eighteenth Century Mexicow, in Essays in the Political, Economic and Social History of Colonial Latin America. Karen Spalding, ed. Delaware, Latin American Studies Program, 1982, pag 35.

2 Taylor, William B.: «Between Global Process and Local Knowledge: An Inquiry into Early Latin American Social History, 1500-1900». In Reliving the Past, O. Zun» ed., Chipel Hill, 1985, pags. 171-172. 
The few histories of urban labor in the colonial period unfortunately still tend to be characterized by reifications of the colonial state, based on its strength, weakness, or naive reflections on its paternalism. The most recent example of the paternalist state interpretation is Doris Ladd's otherwise first rate analysis of the silver miner's strike in Real del Monte in 1767. Ladd argues that «Spanish government sanctioned the grievances of labor and facilitated the worker' victory over the exigencies of expanding capital, creating and old and new accommodation that dignified the place of labor in economic development» ${ }^{3}$. At the other extreme, analyses of urban labor, especially of the tobacco workers, tend to be dominated by uncritical assumptions as to the strength and oppressive nature of the colonial state ${ }^{4}$. While both approaches make compelling arguments, how are they to be reconciled? It is clear, for example, that Ladd's vision of the colonial state's view of labor does little to explain the situation of the textile workers. One of the problems here is that there is a danger of remaining trapped in the not particularly useful dichotomy of the paradigms of a weak versus a strong state, when what would be more useful a systematic analysis of what Peter Evans. Dietrich Rueschemeyer, and Theda Skocpol have called «state capacities», and the "differentiated instances of state structures and actions» whereby as Sckocpol in particular argues «that states are not likely to be equally capable of intervening in different areas of socioeconomic life» ${ }^{5}$.

This brings me to a second point I wish to make. Recent

3 Ladd, Doris: The Making of a Strike - Mexican Silver Workers' Struggles in Real Del Monte, 1766-1775, Lincoln, Nebraska, 1988, pag. 6.

4 See Ros T., Marla Amparo: La producción cigarrera a finales de la Colonia. La fábrica en México. México City, Instituto Nacional de Antropologla e Historia, 44, and La real fábrica de tabaco ¿un embrión del capitalismo?, «Historias», 10, julio-septiembre 1985. Gonźlez Sierra, Jose: Monopolio del bumo (elementos para la historid del tabaco en México y algunos conflictos de tabaqueros veracruzanos: 1915.1930), Jalapa: Universidad Veracruzana, Centro de Investigaciones Históricas, 1987. A less deterministic interpretation is provided by McWatters, David L.: The Royal Tobacco Monopoly in Bourbon Mexico, 1764-1810, Unpublished dissertation, University of Florida, 1979.

5 Evans et al.: «Toward a More Adequate Understanding of the Statew in Bringing the State Back In, pags. 350-351. 
irends in labor history have questioned the wisdom of analysing workers' actions within a teleological framework which judges those actions according to the degree to which politicization and class consciousness is developed, or not as the case may be. Invariably, such interpretations assume that the workers remain passive agents who contribute to their own continued subordination and exploitation. Again, to take Doris Ladd's study, even though the author has provided what is probably the best reconstruction we have of silver miners' voices, she argues that their victory created an obstacle to their own best interests as «the flow of workers' class consciousness» was directed into «the mainstream of royal patronage»". The studies of the tobacco workers previously mentioned portray the workers as passive in the face of state reform, assume the exploitative nature of their working conditions, and in the process reduce the workers to objects rather than subjects ${ }^{7}$. I am not implying that we should engage in a «meaningless empiricism», simply that:

If the formation of social and political relations is neither the product of a predetermined teleology nor a reflex of a social base, it is...a process that reflects the active engagements of labour. This engagement takes a variety of forms, but it is the actual process that must be the key focus of historians....

It follows...that the process that creates the structuring of labour's relationship to society is composed of inherently ambiruous and contradictory elements. It is the presence of differing quantities and types of "subordination" and "resistance" of "class consciousness"... of "hegemonical" influences and "independence", that composes the character of the wider structures of social relations...The trick for the historian is to see how they operated as a process without losing 1 sight of the historical transience of their particular forms 8 .

A subordinate concern, therefore, of this paper, is to examine how the tobacco workers defined and defended their in-

\footnotetext{
6 Ladd: The Making of a Strike..., pas. 122.

7 See Ros: La producción cigarrera...

8 Price, Richard: Labour in British Society - An Interpretative History, London, 1986, pags. 1-11.
} 
terests. My approach to the consideration of state-worker relations is very much influenced by the works of labour historians Michael Sonenscher and Richard Price, both of whom argue that to understand working class formation, labor movements, and the role of the state, scholars should avoid «the teleology of writing labour history as either conforming to or deviating from a certain trajectory. By doing so, this shifts one's perspective to examine the workers' on their own terms, according to their own logic and takes into account the constraints under which they operated. This is to not to imply a regression to meaningless empiricism, but to examine the variations in state capacities".

This brings me to the central argument of this paper. If the object of, the colonial state in relation to the tobacco workers, effectively their employees in the royal tobacco manufactories, was to contain, rather than provoke, social conflict, then for the mos part, it succeeded. The Mexico City tobacco manufactory, like many other early manufactories, was not a "crucible of consciousness nor an epicenter of rebellion» ${ }^{10}$ But, during the state-building process of the Bourbons and the monopolization of the tobacco trade, the workers proved themselves capable of defining and defending their interests, and in shaping work in the manufactories to satisfy their own needs. In the process, they helped to shape the limitations of the Bourbon absolutist state and its powers as an employer through an ongoing process of negotiation. The workers rarely engaged in collective protest - two walkouts and one strike in almost half a century. But perhaps the lack of collective protests indicates not their weakness or unsophistication, what Michael Sonenscher has termed the «immaturity» of labor in the eighteenth century, but the workers' ability to bring pressure to bear upon their employer, in their case, the colonial

9 Price: Labour in British Society..., pags. 7, 12. See also Sonenscher, Michael: Work \& Wages - Natural Low, politics \& the eighteenth century French trades, Cambridge, 1989.

10 Pertot, Michelle: «On the Formation of the French», in Working Class Formution, Ira Katznelson and Aristide Zolberg, eds., Princeton, 1986, pag. 89. 
state, to satisfy their demands without having to resort to collective protest. As I shall argue, however, there was something more at stake in the contention and conflict which developed between the monopoly and the tobacco workers than simply a question of wage levels or retention of customary practices. The workers' actions and grievances illustrate not only attempts to preserve their material conditions but a wider process of cultural assertion in the face of Bourbon modernization which valued independence and upheld the moral obligations of the monarch. The discourse used by the workers to make such assertions was shaped not by the vocabulary of, and the precepts and canons of Spanish law per se but by popular religion ${ }^{11}$. As such, the workers' defense of their interests was founded on belicfs and ideas -ideology may be too grandiose here - which competed with those of the coIonial state: the former based on popular religion, the latter on increasingly secular, rational ideology which laid the foundations for Mexican Liberalism ${ }^{12}$.

Back to the beginning then with the simple observation that monopoly-worker relations were characterized, for the most part, by a functioning consensus borne of negotiation and compromise, rather than conflict. Why? There are seveial reasons which provide an explanation. First, the opportunities for, and conditions of, work in the manufactories. There were few alternatives for work in the cities for semi- and unskilled workers, particularly for women. The tobacco manufactories provided one of the best opportunities for survival in late eighteenth century Mexico. Second, the paternalist ethos of the manufactory and its establishment of dispute pro-

11 Raul Carranca y Trujillo argues that gulld regulations constituted regular legislation for labor but that it was the Recopilacion de las Leyes de los Reynos de las Indias could be considered a legitimate labor code and they the Leyes made up a body of law in many respects without equal for their time. See: Las ordenanzas de gremios de Nueva España, «Crisol», Mexico, 1932. Ladd elaborates on Carranca's argument and concludes: «There were libraries full of labor legislation in Madrid and Mexico City... Spanish government had not only the power to intervene in capital enterprises.... and refers to the «time-honored formula to oblige the crown to intervene on the workers' behalf», The Making of a Strike, pag. 122.

12 Lynch, John: Bourbon Spain, Oxford, 1989. Maclachlan, Colin M.: Spain's Empire in the New World - The Role of Ideas in Institutional and Social Change. Berkeley, 1988. 
cedures, which drew on long established traditions of the Spanish state, institutionalized and channelled conflict and dissipated worker conflict. Third, the organization of work and wages contributed to divisions within the workforce, which were reinforced by existing divisions based on status, gender, and ethnicity, which prevented the formation of a broader class identity among the workers. Fourth, the wider imperial objectives of the colonial state favored social stability in its cclonies which contributed to decisions made in favor of worker demands, and which, in turn, perpetuated the legitimacy of the Bourbon polity.

Part of the explanation must also be sought in the methods employed by the state to establish the manufactories and the organization of production. Between 1769 and 1780 six state managed tobacco manufactories were set up in Mexico City, Orizaba, Puebla, Guadalajara, Oaxaca, and Querétaro. At the same time, private tobacco stores and manufactories were abolished throughout the viceroyalty. The flagship of manufactories was located in Mexico City, the very heart of the administrative and commercial capital of the viceroyalty of New Spain, and which at its peak, employed almost 9,000 workers. It is the Mexico City manufactory which forms the focus of this paper.

The abolition of the tobacco shops took almost ten years to complete with the intention of allowing the workers to adjust to such reorganization. Those individuals affected were assured of alternative employment in the manufactories. For those disgruntled tobacconists whose businesses had been destroyed, they were placated with the offer of lifetime position in the manufactory in the high paying supervisory positions. As a result, workers were incorporated as collaborators in the establishment of the manufactories and acquired a vested interest in the monopoly's existence. The monopoly presented itself as a paternal employer willing to assure workers of employment with similar rates of pay and «perks» given to them in the private workshops. 
The paternalist ethos was conveyed in the informal name given to the manufactory, The Casa del Rey (House of the King), further supported by the use by the workers of the term El Rey Padre (the Father-King). The manufactory functioned as a microcosm of colonial Spanish rule, in which the ideal of political authority and religious orthodoxy was constantly promoted and upheld, and where, guided by its «unwritten constitution» the state encouraged negotiation, and compromise ${ }^{13}$.

Work conditions and organization reflected monopoly paternalism in several ways which encouraged workers to remain in the manufactories. The manufactories offered work cn a relatively regular basis. Seasonality of work did not affect the workers in the tobacco manufactories to the same degree as it did in other trades. There were fluctuations in the working week and year but the extant time sheets suggest a relatively regular working year based on a six day week, punctuated by the normal religious holidays ${ }^{14}$. The periods during which workers could be laid off coincided with shortages of paper supplies or adjustments in production levels. During reductions in production of cigars and cigarettes, instead of laying off workers, production quotas were divided on a pro rata basis so everyone could earn something. When it was necessary to close the manufactory for several days or weeks (which was very rare) the monopoly advanced loans to the workers. Since the demand curve continued upward into the first decade of the nineteenth century, however, regular production ensured regular work for those workers who wanted it. The Concordia, the workers' trade confraternity or mutual aid society, provided rudimentary social insurance against illness and death.

The transfer from private to public management of the

\footnotetext{
13 Phelan, John Leddy: Authority and Flexibility in the Spanish Imperial Bureaucracy, «Administrative Science Quarterly», 5, n.० 1, June 1960.

14 Archivo General de la Nación (AGN), Tabaco 356. Razón de las tareas..., accountantgeneral, 23 July 1781.
} 
tobacco industry incorporated change as well as continuity, transformation as well as modification in the organization and conditions of work. As a result, it is likely that the daily routines associated with tobacco manufacture in the private workshops, although modified, continued within the manufactory to bridge the home and workplace and thus made the impact of the manufactory regime less sharp than has been argued.

Perhaps the most significant bridge between work and home was the «putting out» practice of the manufactory. $\mathrm{Ci}$ garette rollers received quantities of paper based on their daily quotas, tareas, every evening to prepare at home for the following day's work in the manufactory, preparation which they often carried out with the aid of their families. In addition, the manufactory eventually established an escuela de amigas in the manufactory to take care of nursing babies and young children, the formalization of an informal practice by women workers since the first day they began working in the manufactories. The ability to bring children into the manufactory, and to prepare part of a day's work at home permitted a flexible integration of productive and domestic labor, and some continuity with past practice.

The «benefits» of working in the Mexico City manufactory are reflected in the supply of labor. The manufactory ittracted labor despite work in hot, unhealthy, and cramped conditions. It became one of the most important industrial activities in late eighteenth century Mexico. By 1790, tobacco workers comprised approximately 12 per cent of the economically active population of Mexico City. The tobacco workers made up 55.1 per cent of all workers engaged in industrial work who received a cash wage, followed by textile workers who made up 13 per cent, and, in third place, workers in food production who made up 9.3 per cent ${ }^{15}$. Between 1770 and 1810 , the number of workers in the Mexico City manufactory increased from 5,600 in 1771 to a reported 8,988 in 1796.

15 Ros: La real fábrica..., González Angulo Aguirre, Jorge: Artesanado y ciudad a finales del siglo XVIII, Mexico City, 1983. 
As a result of policies to reduce worker numbers, by 1809 , the Mexico City workforce decreased to 5,437.

What we have here then, is a mutuality of interest but a mutuality which was constantly challenged and renegotiated with costs to both sides. As Richard Price argues:

men and women finding themselves in certain social relationships which involve authority and obedience are constantly struggling over the limits, the frontiers at which obedience begins and ends. It is in the continual search from both sides for a better bargain that the dynamic of the labour process in labour's history can be seen to lie 18 .

The search for the «better bargain» brings us now to a consideration of the respective agendas of the monopoly administration and the workers. Y will examine the former briefly, and then go on to discuss more extensively worker associations, their interests, how they set about defending them, and with what success.

Bourbon reform measures sought to increase the strength of the state and the prosperity of its subjects, to produce a «culture utilitaire et culture dirigée» ${ }^{17}$. Throughout the eighteenth century, the colonial state was haunted by fears of political disorder and the degeneration and immorality of $\mathrm{Me}$ xico's lower classes. Both private and public life came under the scrutiny of the Bourbon reformers, and it seemed at times as though the colonial state waged its own internal war on popular culture ${ }^{18}$. Drinking and gambling were regulated, the popular expression of religious practices was attacked, and, the forces of law and order were expanded ${ }^{19}$. Regulation of

16 Price, Richard: The labour process and labour history, «Social History», vol. 8, n. 1, January 1983, pág. 62.

17 Lynch: Bourbon Spain, pag. 261.

18 See Haslip Viera, Gabriel: "The Underclass», in Cities and Society in Colonial Latin America. Louisa Schell Hoberman and Susan Migden Socolow, eds. Albuquerque, New Mexico, 1986. Scardaville, Michael: Alcobol Abuse and Tavern Reform in Late Colonial Mexico, «His. panic American Historical Review», 60, n.० 4, November 1980. Brading, D. A.: Tridentine Catholicism and Enlightered Despotism in Bourbon Mexico, «Journal of Latir. American Studies*, 15, pags. 1.22, May 1983.

19 Ibidem. 
movement, of space, of morals, provided the backdrop to the social advantages the manufactories offered in addition to their profit potential. Manufactory discipline and social discipline were inseparable.

Although the manufactories themselves were not a response to changing technologies or industrialization, but to fiscal pressure, their organization and management created a series of problems typical of many early industrial establishments. Attempts at internal regulations and their daily enforcement depended upon the much wider problem of maintaining a regular work force. It is a commonplace now that the concentration of large numbers of workers and their sub. jection to work discipline "was one of the most difficult problems encountered by early factory masters. Cheap labour was of no advantage unless it could be effectively transplanted from the traditional to the modern sector» ${ }^{20}$ The Mexico City tobacco workers proved to be no exception. As such, the tobacco manufactories provided a miniature version of the Bourbon project to reform and control the colonial populace. Within this context the directorate-general viewed the manufactories' role as a vehicle through which to create not just discipline and order, but:

the perfect school to instruct all who work there not only in their tasks but in all those qualities which make a civil man...because in the manufactory every person lives subject to the voice which commands 21 .

In the minds of the bureaucrats, then, good workers and obedient servants of the state were synonymous. Manufactory

20 Mokyr, Joel: «The Industrial Revolution and the New Economic History», in The Economics of the Industrial Revolution, Joel Mokyr ed. New Jersey, 1985, pag. 30. See slso Cohen, Jon: Managers and Machinery: An Analysis of the Rise of Factory Production, aAustralian Economic Papersw, 20, n.० 36, June 1981. Cohen argues that \&It was at least in part because of the problems associated with managing workers (the riskiness of the undertaking) that so many early factory masters proceded with such caution», pag. 37.

21 AGN, Tabaco 49, Manifiesto que se hace en defensa de las fábricas de cuenta de S.M. en su Real Renta del Tabaco de Nueva España, sus utilidades, y bien común de la gente cperaria, de ambos sexos que trabaja en ellas y sus cualidades contra el equivocado concepto del Real Tribunal del Consuladd de México (hereafter referred to as «Manifiesto»). 
regulations provided the basis through which to inculcate habits of regular, diligent work, sobriety and obedience. Three broad groups of infractions which the administration sought to eliminate to improve organization and discipline may be identified as follows: (1) those which related to achieving a reliable, organized work environment by penalizing late arrival to work, failue to register with the manufactory guards, theft of monopoly goods, inefficient use of raw materials; (2) those which mandated obedience and which regulated worker - supervisor relations - disobedience and physical attacks on supervisory staff or on other workers were all penalized; (3) those which encouraged good morals and «civil» behaviour by punishing drunken or offensive behaviour, gambling and card playing in the manufactory, gossip, and other «scandalous» behaviour. All these infractions carried gradations of punishment which ranged from a stint in the manufactory stocks, payment for materials wasted, suspension from work to permanent prohibition from employment in any of the state tobacco manufactories ${ }^{22}$. Herein lies one of the critical differences between monopoly and worker objectives: manufactory regulations transcended the limits of the workplace and demanded reform of workers' morals and social mores, a reform which impinged upon their wider popular culture ${ }^{23}$. The resentment of attempts to reform the workers' general lives is reflected in their grievances and actions which convey an underlying concern with their ability to live their lives as

22 AGN, Tabaco 146. Ordenanzas de la Real Fábrica de Puros y Cigarros, 15 June 1770; AGN, Tabaco 67, «Prevenciones de la dirección general, que deben observarse exactamente en la fábrica de puros y cigarros de esta capital, así en las oficinas de hombres, como también en las de las mujeres mientras no haya nuevas órdenes que deroguen algunasw, 20 March 1792.

23 As has been argued for economic reforms promulgated against the journeymen in eighteenth and nineteenth century Europe: «reform... promulgated by... the authorities, was directed not only against a specific form of economic but also against a specific form of popular culture. Thamer, Hans-Ulrich: «Journeyman Culture and Enlightened Public Opinion» in Understanding Popular Culture-Europe from the Middle Ages to the Nineteenth Century, Steven L. Kaplan ed., Berlin, New York, 1984, pag. 227. The literature on early factory organization demonstrates similarities in terms of structures and the content of rules imposed on workers. See Bendix, Reinhard: Work and Authority in Industry-Ideologies of Management in the Course of Industrialization, New York, 1956. 
the saw fit, and not according to the mandates of the colonial state.

The state was less than successful in disciplining its manufactory workers. As late as 1817 , the director-general reported that the standard of manufactory cigars and cigarettes still left a great deal to be desired and resulted in constant losses to the monopoly as consumers sought out contraband products ${ }^{24}$. In the long term, however, the state's gains from the tobacco monopoly were considerable. The Bourbons took over an industry which experienced an increase in profits from one million to four million pesos, and an increase in the volume of production of cigarettes from 40 million to 120 million packets. In the process, the monopoly administration demonstrated the double-edged nature of its paternalism. As Patrick Joyce has pointed out, the affective and coercive are rarely strangers in paternal and deferential relations ${ }^{20}$. The paternalist ethos of the manufactory certainly did not prevent the directorate-general from implementing reforms which increased the profitability of the monopoly at the expense of the workers, nor to use the power of the state (legal, religious, and military when necessary, although rare) to control the workers. The monopoly proved to be at its least paternal in the gradual reduction of piecework rates for the cigarette rollers during the $1790 \mathrm{~s}^{20}$. The tobacco workers, like many other urban workers experienced the effects of late colonial inflation. The monopoly also gradually abolished many (not all) of the non-monetary «perks» («bonuses» for chocolate and free cigarettes to smoke while «on the job») traditionally received by cigarette and cigar rollers during the 1780s and 1790 s and, at the same time, introduced fines to penalize workers who wasted tobacco or paper. How the workers co-

24 Archivo General de Indias (AGI), México, 2.302, report of López, 10 November 1817.

25 Joyce, Patrick: Work, Society and Politics: The Culture of the Factory in Later Vic. torian England, New Brunswick, 1980, pag. 95.

26 There were a few increases registered at the supervisory levels and the practice of individual petition permitted some workers to improve their own position. As such the inanufactory workers fared no better than other urban workers in colonial Mexicu. 
ped with such changes, what they perceived to be their interests, and how they defended them are the questions which I shall now consider.

There is no evidence that the tobacco workers were orranized within a guild prior to the monopoly. One of the major changes in the workers' lives incorporated the ability to form associations on a scale impossible in their previous situations dispersed throughout Mexico City. The associational lives of the tobacco workers were shaped through a variety of institutions and social relations which incorporated both work and home, through the occupational cuerpos within the manufactory, and the trade confraternity or mutual aid society, the Concordia, through family, and neighbourhood, church and tavern. Such associations enabled the workers to act collectively yet contributed to social cleavages among them. If anything, the workers' actions resemble what Alf Luedtke has identified as eigensinn, observed in the case of German factory workers, the phenomenon whereby the work experience and domestic situation promoted a sense of collective identity and, at the same time, a corresponding sense of individualism ${ }^{27}$.

The colonial state exhibited ambiguity towards corporate bodies in the late eighteenth century. On the one hand, it carried out an offensive against trade guilds and the corporate structure of the Church. On the other hand, it was instrumental in supporting the creation of new corporate entities such as the military fuero and the mining guild primarily to create a sense of identification, with and loyalty to, the state. The tobacco workers proved to be beneficiaries of the latter practice. Indeed, it was the concentration of such large numbers of workers in one place which provided the imperative and conditions for the development of such corporate orga-

27 Luedtke, Alf: «Cash, Coffe-Breaks, Horseplay: Eigensinn and Politics Among Factory Workers in Germany circa 1900w, in Confrontation, Class Consciousness, and the Labor ProcessStudies in Proletarian Class Formation, Michael Hannagan and Charles Stephenson eds. New York, 1986, pags. 65-96. 
nization within the Mexico City manufactory. The workers, on their own initiative, requested permission to organize a confraternity, the Concordia. The colonial state agreed to its establishment and approved its regulations. In so doing, it increased the dependence of workers upon the monopoly if they were to benefit from their weekly monetary contributions, but simultaneously the Concordia became the workers' symbol of independence and security.

The visitor-general and architect of the tobacco monopoly, José de Gálvez approved of an institution which enabled the manufactory workers to «clothe the naked, aid the sick and ensure decent burials for their members» ${ }^{28}$. A doctor was appointed at an annual salary of 250 pesos paid for out of Concordia monies. If the Concordia's main function was to provide monetary benefits to support workers during illnesses, and their relatives after their deaths, it also functioned as a source of credit from which workers could borrow money to cover costs of marriages and baptisms, and the daily cash needs when the manufactory was closed because of fiesta days.

The Concordia's General Ordinances were drawn up in 1770 and approved by a Royal Order of 24 May 1771. Both male and female workers were eligible to join. By the end of 1771 , the Concordia's membership totalled 5,600 ${ }^{20}$. Tobacco workers who wished to become members of the Concordia were requested to contribute $1 / 2$ real on weekly basis. The Concordia's governing officials consisted of the manufactory administrator as director, with two head foremen elected as accountant and theasurer, and eleven conciliarios (representatives) chosen from the different manufactory cuerpos, including the cigarette workers. Concordia funds were quite considerable. Surplus funds were used to invest in property which included houses in the calle Lagunilla and the calle

28 AGN, Tabaco 49. Manifiesto...

29 Ibldem. 
Berdeja, rooms of which were rented out to workers. By 1793, total income reached 42,346 pesos ${ }^{30}$.

At the centre of the Concordia's establishment was the election and veneration of a patron saint. Originally the Concordia members chose two patrons: San Isidro Labrador and the Virgin of Guadalupe ${ }^{31}$. San Isidro Labrador became the major patron saint and an image of him was commissioned by the officials of het Concordia which, on completion, was placed by the workers in the church of Santiago Tlatelolco. Every May 15, his saint's day was celebrated with a mass and sermon and «all the solemnity and pomp possible» ${ }^{32}$. The Virgin of Guadalupe, nevertheless, continued to play an important role in the lives of the workers who often called upon her as their divine mediator and signed their petitions in «the name of the Virgin of Guadalupe» ${ }^{33}$.

It was not only the Concordia, however, which provided the main focus of worker identity, but the individual cuerpos. The latter were organized around the different manufactory tasks of wrapping, shredding, rolling, stamping, packing, to give a few examples, and it was the cuerpos which represented workers' grievances to the manufactory administration, not the Concordia. The existence of these two corporate entities, however, created tensions as workers were brought together through membership in the Concordia, while the cuerpos divided them again according to their task specific problems. I will return to this point in a moment.

30 AGN, Tabaco 480. Rafael Lardizabal, juez protector de la Real Concordia, to viceroy Calleja, 6 July 1814. No records of the Concordin were found after 1793. Scattered references and another controversy which involved disposal and distribution of Concordia funds between 1813 and 1814 indicate that it continued to operatc throughout the first decades of the nineteenth century.

31 AGI, México, 2.259, maestros de la mesa adjunta de Concordia, 15 January 1776.

32 AGI, México 2.313. Testimonio del Quaderno que contiene la Real Orden sobre el Establecimiento y Arreglo de la Concordia de la liabrica de puros y cigarros.

33 AGN, Tabaco 393, los operarios y operarias de oficinas de puros de la Real Fabrica ti) administrator, 29 February 1820. See Taylor, William B.: The Virgin of Guadalupe in Neu Spain: an inquiry into the social bistory of Marian devotion. «American Ethoologist», vol. $14, n .^{\circ} 1$, February 1987. 
The residential patterns of the workers suggest that many of the workers and their families lived concentrated together in barrios close to the Mexico City manufactory ${ }^{34}$. The parish of Santa Catalina Martyr was a popular neighbourhood for many of the workers and their families, who attended mass and were confessed in the local churches. Single tobacco workers also lived in the same casas de vecindad (tenement hou$s \in s$ ) as other tobacco workers ${ }^{35}$. Another common social milieu for gatherings were the pulquerías. In the parish of Santa Catalina Martyr, for example, there were four very popular ones, la Celaya, la Aguila, la Vizyaga and las Papas frequented by the workers, much to the dismay of the ministers of the Royal Court of Audit who observed that: «it was not uncommon for almost 1,500 workers, most of them from the manufactory, to go to the pulquerías on their way home from the manufactory during the week» ${ }^{36}$. Gambling was an equally popular pastime for the tobacco workers. Indeed, Michael Scardaville found that cigarette rollers were arrested for gambling twice as often as the next most important group, the weavers ${ }^{37}$.

If the associations had a mixed impact upon the workers' organization, so did the composition of the manufactory labor force, distinguished and divided by status, family, occupation, ethnicity, income, and gender. Historians who have argued that the reorganization of the private tobacco shops transformed the tobacco shop owners and their workers into an homogeneous workforce of wage earners, have overstated the

34 Ros: Le producción cigarrera..., pags. 70-75.

35 Brun Martínez, Gabriel: aLa organización del trabajo y la estructura de la unidad doméstica de los zapateros y cigarreros de la ciudad de México en 1811", in Organización de la producción y relaciones de trabajo en el siglo XIX en MÉxico, México, INAH, Cuaderno de Trabajo, 29, pag. 153.

36 AGN, Tabaco 241, Real Tribunal y Audiencia de la Contadurla Mayor de Cuentas de México, 9 March 1796. Seq Scardaville: Alcobol Abuse and Tavern Reform in Late Colonial Mexico. He argues that: «The drinking house functioned as a reassuring institution in a society kept in a constant state of flux. With accelerating corn prices, periodic epidemics, and job insecurity, the tavern, was a pillar of strength in a time of uncertaintyw, pag. 218.

37 Scardaville, Michael C.: Crime and the Urban Poor: Mexico City in the Late Colonial Period. Unpublished disertation, University of Florida, 1977. «More than 7 per cent of all arrests involved cigarette makers. See Chapter Two, footnote 40, pag. 75. 
case ${ }^{38}$. If the reorganization of the tobacco trade accelerated proletarianization, it was on very uneven terms, both in a material and an ideological sense.

We know that the people who made cigars and cigarettes were a diverse group composed of small entrepreneurs who employed between thirty and forty rollers, artisans in their workshops who relied on their families for labor, and women who made cigarettes at home on a putting out basis. It was from such divergent backgrounds that the Mexico City manufactory's work force was recruited. The differences were made greater when the colonial state began to use positions in the manufactory as pensions and forms of patronage for Spanish widows, retired military or retired bureaucrats.

The manufactories employed the former tobacco shop owners and their families of whom, according to the directorgeneral Silvestre Díaz de la Vega, there were «a considerable rumber... (including children) - who work in the fábrica» ${ }^{39}$. Outside of such occupational families, male workers tended to be married, while female workers were more likely to be single or widowed. One study of the manufactory workforce (based on a sample of 1,753 cigarrette rollers) suggests that by 1811 , the majority of male tobacco workers were married in comparison to 72 per cent of the women who were either single o widowed ${ }^{40}$.

Tobacco workers were recruited from different ethnic groups but supervisory positions, such as head foreman and women, table foremen and women, and guards were dominated by peninsulars and creoles ${ }^{41}$. Gabriel Brun's analysis of the 1811 census showed that 69 per cent of the sample of

\footnotetext{
38 Ros: La producción cigarrera..., pas. 44.

39 AGI, Mexico, 2.264. Dlaz de la Vega to Exc. Sr. 22 January 1798.

40 Brun Martinez: «La organización del trabajo...», pag. 147.

41 Ros T., Marla Amparo: «La real fábrica de puros y cigarros: organización del trabajo y estructura urbanaw in Ciudad de México - Ensayo de construcción de una bistoria, Alejandra Moreno Toscano, ed., Mexico City, INAH, 61. Ros' analysis of the Padrón of 1800 for Mexico City indicates that of 7,074 manufactory workers only 525 (7.4 per cent) were Indian tributaries. Within their total number, she calculated that they constituted 7 per cent of the total number of pieceworkers which was equivalent to 88 per cent of all Indian workers. No Indians were found in the ranks of the administrative personnel.
} 
tobacco workers were Spanish, 16 per cent were Indian and 15 per cent, castas ${ }^{42}$. Finally, the Mexico City manufactory workforce also incorporated migrants from rural areas who made up approximately one-third of the workers ${ }^{43}$.

Differentiation within the workforce was reinforced according to income and occupation, and by whether a worker was on piecework or earned fixed wages. As with any other trade, the real level of a worker's income depended upon the comestic situation of the worker. If an entire family was emFloyed in the manufactory, the collective total of weekly wages could actually be quite lucrative. Single wage earners, particularly if they were cigarette rollers on piecework, however, barely earned a subsistence wage. The variations in income were wide and ranged between 87 pesos to 560 pesos (based on a 260 day work year).

The workforce was divided among eleven separate task categories which incorporated the administrative, supervisory, and manual tasks. Despite such divisions, it must be emphasized that the cigarette rollers, all of whom were on piecework, tormed the overwhelming majority of manufactory workers - 81 per cent of the total workforce, followed by cigarmakers who comprised 6 per cent of the total workforce. What is significant, however, is that the cigarette rollers, instead of forming a homogeneous group of pieceworkers levelled by the division of labor within the manufactory created new identifications and boundaries which reinforced corporate vertical ties. Possibly as a response to loss of control over hiring practices and status, the older cigarette rollers distinguished themselves as professional cigarette workers, de la profesión (and by implication, skilled), as opposed to those workers who were employed in later years, literally «from the street» de la calle (by implication, unskilled). The distinction was pointed cut by workers who considered themselves de la profesion on several occasions to justify complaints against reduced work

42 Brun Martínez: «La organización del trabajo...», pag. 147.

43 Ibidem. 
quotas at a time when they perceived that workers classified by them as de la calle, were still being hired ${ }^{44}$.

The variety of associational forms among the workers reinforced divisions among the tobacco workers throughout the eighteenth and early nineteenth centuries. They maintaiised vertical as well as horizontal ties based on corporate divisions, and their loyalties remained with the king, their families, and their priests, not to one another in the sense of class identification.

The objectives of the tobacco workers' actions, however, were not to challenge the monopoly or the state - the source of their security - but to defend what they perceived to be their rights which included a particular way of life, the very one the colonial state attempted to extinguish.

A review of worker petitions and actions reveal five broad categories which brought the workers into conflict with the monopoly: management of time and work discipline, fraud and abuse of power by supervisory staff (including intimidation and physical abuse); wage levels; violation of customary practices (provision of non-monetary «perks», access to raw materials); and hiring practices (this included both unfair dismissal and securing positions for relatives).

The Mexican tobacco workers' responses to their new work regime resemble those of many other workers subject to :imilar changes such that:

It is clear that the introduction of factory regulations fixed neither the extent nor the content of work time...the workers...pursued a varying... struggle to control the expenditure of their labour power. These battles were extensively concealed aad aimost always unspectacular 45 .

44 AGN, Tabaco 358. Maniau y Ortega to director-general Díaz de la Vega, 11 September 1797.

45 Luedtke, A. L. F.: «The Historiography of Everyday Life: the Personal and the Political», in Culture. Ideology and Politics, R. Samuel and G. Stedman-Jones, eds., London, 1982, pag. 44. The literature on worker response to changes caused by increasingly capitalist relations is immense. One provocative set of essays is contained in Kaplan, Steven L. and Koepp, Cynthia J.: Work in France - Representations, Meaning, Organization, and Practice. Ithaca and London, 1986. For a compelling analysis of resistance, its process, and manifestations, see Scott, James C.: Weapons of the Weak-Everyday Forms of Peasant Resistance, New Haven and London, 1985. 
Manufactory regulations give the impression of an orciered and uniform work day yet practice suggests something rather different. The time constraints to which the workers were required to adhere remained remarkably flexible largely due to piecework. For supervisers, the working day began at $\tau$ a.m. for the men, and 7,30 a.m. for women, and could finish any time between 5 p.m. and 8 p.m. Technically, the cigar and cigarette rollers of both sexes could be admitted to the manufactory until 8.30 a.m. after which time no worker was allowed to enter. At 9 a.m., along with those for whom there were no tareas, those who did not choose to work also left after having collected their paper quotas for the next day; at noon, those workers who wished to leave coud do so. Finally, from 3 p.m. until 4 p.m. workers could leave as they finished their day's work. Thus, the working day could extend for the supervisors from between ten and twelve hours, while for the cigar and cigarette rollers, anywhere from five to eight hours.

The manufactory administrator elaborated on the problems of enforcing regular work habits «since the workers have always been able to come and go from their work as they please» ${ }^{40}$. The problem was not that workers did not go to work each day but that they often only worked for half a day and left at noon only having completed a proportion of their tareas ${ }^{47}$. Even after the manufactory administrator successfully engineered the reduction of the Mexico City work force between 1795 and 1798, with an eye to a more rationalized work force, he continued to complain of problems related to a more disciplined, regular work force. Puchet reported that cn one day approximately 4,900 tareas were distributed based on the number of workers listed. Yet no more than a total of 3,600 were completed leaving 1,300 unfinished due to «the continuous and voluntary lack of attendance by workers on

46 AGN, Tabuco 241, Díaz de la Vega to viceroy Azanza, 31 March 1799.

47 Ibldem. 
c. regular basis ${ }^{48}$. By the beginning of the nineteenth century, however, the director-general still complained that levels of production remained uncertain due to discretionary attendance by some of the workers ${ }^{49}$. We must also bear in mind that these are observations and simply that, and tell us nothing about the frequency of worker absenteeism, undoubtedly less than bureaucratic reports would have us believe, given the volume of cigarette production annually. Indeed, this is certainiy the case for the supervisory workers who demonstrate a very low turnover within their group which suggests at least a minimum satisfaction with their positions. In the case of the female supervisory staff, by 1812,39 per cent of the total supervisory staff entered the Mexico City manufactory between 1771 and 1780, and possessed an average of 37 years' service. If we add on the next decade, fully 63 per cent of the supervisory staff started at the manufactory between 1771 and 1790 and were still listed as working there by $1810^{\circ 0}$. While we are confident in arguing that the supervisory staff demonstrated low rather than high turnover in their ranks, the evidence for the pieceworkers, predominantly the cigar and cigarette rollers is mixed. Monopoly reports suggest there was a ligh turnover among the cigarrerías, especially the men, a characteristic which was also used as a justification for employing women only. The director-general repeatedly complained about the male cigarette rollers and emphasized their shiftlessness epitomized by their continuous migration and the abanconment «of their souls as well as their families so that (the women) find themselves without fathers, husbands, brothers Cr sons»"

Another practice of the workers which illustrates their

48 Ibldem.

49 Ibídem.

50 AGN, Fondo de Real Hacienda, Administración de la Real Renta del Tabaco, Contaduría, Caja 79, «Libro que consta el tiempo y los destinos que han servido las guardas, sobrestantas, maestras, embolvedores y recontadores de esta Real Fábrica de Puros y Cigarros de México hasta fin de diciembre de 1812w, fols. 4215v.

51 AGI, Mexico 2.264, Dlaz de la Vega to Exc. Sr., 22 January 1789. 
continued ability to manage their time in the workplace was known as la voz fletes. Veteran cigarette rollers and supervisors alike «sold» their tarea to their fleteros (generally children or apprentice workers or relatives). While their substitutes (generally less skilled) carried out their piecework quotas, the workers left the manufactory to tend to other needs but returned in time to make the delivery of their tareas to their supervisors. The repeated prohibitions against the practice of fletetos is indicative of the popularity and persistence of the practice among the workers ${ }^{52}$.

The point of all of this is that the workers found ways in which to accommodate their needs by manipulating the work regime without taking to the streets. Discretionary movement in and out of the workplace, made possible by piecework was undoubtedly a response to changing needs of household economies and individual workers alike. Despite the regularity of manufactory work, declining wages and the potential for layoffs only exacerbated uncertainty about daily survival and created imperatives which conflicted with those of the monopoly which demanded regular attendance and careful work habits. Richard Whipp has argued that in constructions of time and work:

The emphasis is on uncertain outcomes. Timing becomes crucial in the experience of work...The points of intersection between an individual's or family's life cycle with wide: economic movements become vital in understanding how people experience work in a total sense ${ }^{63}$.

If the practices of the workers reflected their beliefs of what was fair in the disposal of time and how they used it for their own, rather than the monopoly's needs, the same could be said in their use of monopoly material. By far the most

52 AGN, Renta del Tabaco, directorate-general to Romaña, Betosolo, 2 September 1791. See also the Prevenciones de la Dirección General, que deben observarse exactamente in la Fábrica de Puros y Cigarros... 20 March 1792.

53 Whipp, Richard: «'A time to every purpose': an essay on time and work» in Patrick Joyce, ed.: The Historical Meanings of Works, Cambridge, 1987, pag. 222. 
widespread and controversial practice was embezzlement of manufactory materials: paper and shredded tobacco. Once at the worktable, supervisors and workers alike could take advantage of the materials at their disposal. Despite daily searches by manufactory guards opportunities abounded for workers to take small quantities of tobacco and paper out of the manufactory and to sell them in the streets for whatever price people were willing to pay for them often to acquire additional income to supplement the inadequate one gained from piecework. Paper provided a commodity which could ielp to supplement a worker's income, through its sale, barter or the manufacture of contraband cigarettes. Access to paper for the tobacco workers occupied the same function that the vartido (share of silver ore) did for the mineworkers in colonial Mexico, and certainly generated as much controversy when attempts were made to eliminate it. Not surprisingly, the greatest losses occurred due to the sanctioned manufactory practii $\epsilon$ of preparation of cigarette paper at home. When the cigarette roller returned to work, he was armed with cheap substitute paper bought, or bartered, from one of the stores close to the manufactory. For those supervisors who took their jobs seriously, however, it was not difficult to detect. From the perspective of the monopoly administrators such practices amounted to theft and were punished as such. From the workers' perspective, their «appropriations» may indicate their expectations of retaining non-monetary «perks» ${ }^{\text {of }}$.

Apart from shaping working conditions to their own reeds, the most common method used by workers to defend their interests was the one established by the state - the submission of petitions, a procedure which promoted negotiation ard cooperation. Complaints came from both individuals and cuerpos, and more rarely, as a generalized response which cut

54 John Rule argues that the «criminal» activity among workers in the early factories occurred as, a result of the transformation of the wage from a form in which monetary payment constituted a part (although a substantial one) of the wage, to one based exclusively on a monetary payment». See Rule, John: The Experience of Labour in Eighteenth Century ,English Industry, New York, 1981, pag. 125. 
across such cuerpos. We cannot illustrate each type of grievance but the ones which follow exemplify the modus operandi of petition, negotiation, and resolution.

In 1777, the directorate-general reduced the wages of the cigarette makers of the Patio de Mexico. The workers responded and hired a lawyer to protest the decision. Rafael de Molina, the lawyer in question, argued that the reductions violated the provisions of the boleta given to each cigarette maker prior to beginning work in the manufactory. Following little action on the part of the directorate-general, a petition signed in the name of the "común de cigarreros» arrived on the viceroy's desk. In the petition, the workers complained that many of the former tobacco shop owners had not yet received positions promised to them when the monopoly took over and they were working for low wages. The decision to eliminate bonus payments for chocolate, and additional wrapping tasks created severe hardship among the workers who protested: "There is no law which says that an operario must work more to earn less.» The directorate-general remained unsympathetic, argued that the changes were necessary to rationalize manufactory production and that a petition signed by only 63 individuals was insignificant ${ }^{56}$. No further action was taken by the workers.

Workers' complaints often reflected antagonisms towards manufactory management. Specific individuals became the focus of aggression and represented the physical embodiment of workers' problems, perceived as «bad government». For the workers in the Mexico City manufactory, their nemesis proved to be the administrator. The general consensus among

55 This incident is discussed in full in McWatters: The Royal Tobacco Monopoly..., pags. 156-158. Originally workers received, in additior. to their piecework wage, certain bonuses. For each 3 cuadernos of paper (worked they were paid 1/4 real for chocolates or chocolate drinks and $1 / 2$ real per tarea for envoltura, i.e. the packing of cigarettes into their packets. The workers in the Patio de Mexico were distinctive, in this practice compared to the Patio del Reyno and the Patio de Mugeres. Consequently, instead of receiving 4 or $41 / 4$ reales per tarea they earned $41 / 2$ or 5 reales per tarea. As scompensation» for the abolition of these uperks», a total monetary loss of $41 / 2$ reales per week, the directors-general ordered an increase in the quantity of paper distributed to the, workers. 
the tobacco workers was that the administrator was the «enemy» of all of them, and described him as a «despot» or «tyrant». For his part, the administrator complained of the toll that an excessively large manufactory workforce took on him with the daily flood of complaints and petitions. The workers' grievances concentrated on «maligning others of better merit or me...because I refuse to accede to their requests» ${ }^{\infty 6}$.

At the same time, workers relied upon the directorategeneral to help solve their domestic problems which suggests that they took the idea of paternal obligation seriously. In 1800 , for example, several cigarette rollers petitioned the monopoly to help with excessive rents demanded of them in the Villa de Guadalupe, an adjunct to the Mexico City manufactory ${ }^{67}$. The fiscal finally found in favor of the workers and decreed in 1805 that property owners must maintain their rents at the levels which existed prior to the establishment of the manufactory in the villa ${ }^{68}$.

Individual petitions, which reflected the workforce at its most atomized, also flowed into the administrator's office. In similar manner to the cuerpo petitions, individuals sought wage increases, promotions, pensions, retribution for abusive treatment at the hands of the supervisors, or employment for their relatives - in short, improvement of their existing situation.

The reactions of the colonial state to the workers' penchant for complaint bring to mind a point made by E. P. Thompson in his now much criticized, but still much quoted, article on the moral economy of the English crowd. Thompson argued that «this moral economy impinged very generally upon eighteenth century government and thought and did

56 AGN, Tabaco 482, Puchet to director-general, 12 August 1794.

57 AGN, Fondo Real Hacienda, Caja 121. ,Los operarios de la Fábrica de cígarros de la Villa de Nuestra Señora de Guadalupe sobre exceso en los arrendamientos de casas, 1800, f. 1-15v. The manufactory of Guadalupe was established as an, adjunct to the Mexico City manufactory in 1799.

58 Ibídem, fiscal Borbón, to viceroy, 7 Notember 1805. 
not only intrude at moments of disturbance» ${ }^{59}$. Perhaps this is best illustrated in the Mexican case by the manufactory administrator's decisions which were clearly guided by assessments of workers' reactions, usually negative, to changes in their daily routine. The clearest example is that of the investigation of the misuse of Concordia funds in 1781. The begin1.ing of the investigation coincided with Holy Week. The directorate-general argued that normally, loans were advanced to the workers during the feast but that with the investigation in process, no advances should be made. The administrator countered such a suggestion «knowing the character and way of thinking of these people...we will have a riot aimed at the directorate-general or the Royal Palace to request the loan» ${ }^{\infty}$. For the administrator, the issue was not whether the action suggested was justified but how to avoid conflict. The loans were paid. Even with such pre-emptive actions, however, worker discontent could not always be bargained away.

State-worker relations, for the most part reflect a continuity of Spanish imperial practice which encouraged negotiation and compromise, despite the centralizing and sometimes confrontational actions of the Bourbon state. That resolutions made by the monopoly were not always made in favour of the workers' petitions, and that they did not perpetually take to the streets suggests a general acceptance of the authority which made such decisions and its legitimate right to do so. There were limits to compromise, however, which resulted in collective protest by the tobacco workers. Worker disatisfaction could escalate into crowd action and «bargaining by riot», a strategy which continued to be used by manufactory workers in the $1830 \mathrm{~s}$ and $1840 \mathrm{~s}^{61}$. In the remainder of this paper, I will examine the two most serious examples of state-worker

59 Thompson, E. P.: The Moral Economy of the English Crowd in the Eighteenth Century, «Past and Present», 50, February 1971, pag. 79.

60 AGI, Mexico, 2.313, Isidro Romaña Perez de Acali to director-general Hierro, 9 April 1781.

61 See Lis, Catharina and Soly, Hugo: «Policing the Early Modern Proletarial, 1450-1850*, in Proletarianization and Family History, David Levine ed., New York, 1984, pag. 212. 
conflict which demonstrate the causes and contingencies of such conflict. They serve to clarify further the nature of worker grievances, the responses of the state, and to shed some light on the workers' perceptions of power, authority and a moral order. The first example concerns the unsuccessful attempt of the directorate-general to abolish the Concordia; the second, the workers' strike action in 1794, what I shall term the Paper Riot.

The first example of conflic is not actually concerned with strikes or street violence but a protracted, successful legal battle of the tobacco workers against the directorate-general's attempts to abolish the Concordia. The reasons for such failure are firmly embedded in expediency tinged with humanitarian reasoning. Although the final resolution in favor of the workers worked to the advantage of the monopoly, the workers probably perceived the decision in their favor as a result of a fair investigation which only reaffirmed the paternalistic qualities of their employer.

Between 1770 and 1793 the Concordia's management became the focus of suspicion, attack and investigation. Practically from the founding of the Concordia, from 1770 until 1783 , its funds were subject to abuse and embezzlement by several members of the Concordia's council. The immediate response of the directorate-general and the manufactory administrator was to press for the Concordia's abolition. They argued that concordantes often failed to receive fair compensation in accordance with their contributions. They advised that the Concordia should be abolished on the grounds that the majority of workers neither wanted, nor benefited from its operations, that all loans to workers should be called in, and Concordia property (houses) sold ${ }^{82}$. Behind allegations of such corporate mismangement and abuse of the workers, the evidence suggests that the directorate-general feared the

62 AGN, Tabaco 500, fiscal Posada, 30 April 1781. The directorate-general argued in favour of abolishing the Concordia on repeated occasions, 3 and 6 April 1781, and 13 February 1783. See AGN, Tabaco 500, Bataller, assessor-general, 24 July 1781. 
corporate qualities of the Concordia an the «representative voice so inclined to influence the very movements which one tries to avoid» ${ }^{83}$. The workers, for once acting collectively as a «cuerpo de varias clases», argued that they did not wish their Concordia abolished, only its «despotic management» ${ }^{64}$. The determination of the workers to keep their Concordia is not difficult to understand - for many, it was the only thing which stood between them and destitution.

In a statement to the viceroy, despite threats from the administrator, the workers outlined the reforms necessary to eliminate past abuses: a new election of conciliarios to supervise the management, collection, disbursement and investment c.f Concordia funds and a reassertion of their «right» to elect officers. They requested that the chest which contained Concordia funds be moved out of the manufactory altogether and into the Hospital de San Juan de Dios, and expressed their «right» to decide whether to remain at home when ill or to cnter one of the hospitals ${ }^{* 6}$.

In 1791 , ten year after the initial investigation began, Viceroy Revillegigedo ordered against the abolition of the Concordia and immediate implementation of revised Concordia regulations designed to prevent further abuses. Responsibility of their implementation was delegated to the oidor don Ciriaco González Carbajal in his role as «protector» of the workers ${ }^{\infty}$.

While the colonial state may have taken its Christian and moral duties to protect the poor and encourage them to better themselves seriously, it did so with one eye on profit. The revisions represented a move by the directorate-general to use

63 AGI, Mexico 2.264, director-general to Viceroy, 1797. For full details see AGN, Tabaco 500, Testimonio de los Autos formados sobre extinción de la Concordia.

64 Ibídem.

65 Ibldem, cuerpo de operarios de varias clases to Exc. Sr., 11 June 1781.

66 The elected conciliarios were to be composed of four cigarette rollers, two maestros, two sobrestantes, two guardas, one embolvedor, one recontador, one encajonador, one cigar roller, and one cernidor. The administrator, however, continued as director and possessed a casting vote although the Concordia representatives recognized only the viceroy as their inmediate head and judge. 
the Concordia as a means to enforce what manufactory regulations had failed to achieve - regular attendance of workers. The reforms made access to Concordia contributions increasingly dependent upon both regularity of attendance at work and the length of time worked in the manufactory. Death benefits were restricted to those who had worked in the manufactory for at least eight years and for all other benefits, a ininimum of one year. Those workers who stopped working for at least a month, even though they had paid their weekly contributions, lost their benefits ${ }^{67}$. If they chose to return to the manufactory, «benefits» time had to built up from the time they entered. Those workers who attended regularly year after year, gained the security of access to loans, a daily income when sick, and assurance of a decent burial; those who did not found themselves excluded from Concordia benefits. All of this was predicated on the assumptions that efficient records would be maintained to prevent further abuse, fraud and embezzlement ${ }^{68}$.

Interpretations of the Concordia and the decision of the colonial state to permit its continuation vary. Some historians argue that it became the «tool» of the monopoly through which to dominate and control the workers ${ }^{60}$. I do not disa-

67 The presence of forasteros in the manufactory workforce was acknowledged and given consideration. Workers whose families lived outside of Mexica City were permitted time off to travel to see them. Provided they acquired the requisite permission to travel from the Administrator, on their return, they would not lose their benefits. AGN, Tabaco 500 .

68 A.G.I., Mexico 2.313, viceroy Revillagigedo to Conde de Lerena, 27 July 1791.

69 Ros views the Concordia as a response to the need to defend the family economy in the wake of the impact of the manufactory upon the workers, which, in the process, became an organ of control of the manufactory administration, and that it was never for the purposes of the defense of labor, salaries or even to improve the conditions of work. Ross: Le produccion cigarrera... pags. 82-83. For an interpretation of the Concordia as the state's.exploitative mechanism for ensuring the reproduction of the manufactory's labour force, see González Sierra: Monopolio del bumo..., pags. 60-61. Given . late eighteenth century social conditions, González Sierra's interpretation borders on the anachronistic, distorts its function, and minimizes the workers' role in the organization of the Concordia, and their support for its continued existence. Ives Aguila sees the Concordia as a stepping stone to the formation of trade union, in Agulla, Yves: Albores de la seguridad social en México, 1770: La Concordia de la Manufactura de Tabricos, «Jahrbuch Für Geschichte von Staat, Wirtschaft und Gesellschaft Lateinamerikas», 24, 1987, pags. 351-352. 
gree that the Concordia was used to strengthen control over the workers' movements and to enforce regular attendance but I would make two additional observations. Since there was no outcry against the revised Concordia regulations, this may reflect approval of them by many of the workers who worked regularly, expected to receive the benefits from their contributions, and wanted a more honest management of their funds. I would also argue that the Concordia possessed a wider symbolic importance for the workers which transcended the issue of reformed regulations and which countenanced their sense of independence. Suggestive here is their concern with the ability to control both institutional and personal space as illustrated by two of the workers' demands already cited: removal of the Concordia treasury from the actual physical space of the manufactory to the Hospital de San Juan de Dios, and the workers' insistence on their right to choose where to be ill ${ }^{70}$. The first was not implemented, but workers retained the right to choose whether to be cured in hospital or in their homes.

The second example of conflict relates to the tobacco workers' first, and as far as the evidence suggests, only attempt to organize a strike. The origins of the controversial reform which culminated in the call for a strike are to be found in monopoly attempts to rationalize production and to reduce theft and waste of cigarette paper. The paper used in the manufactories was imported from Spain. While Spain's wars and embargoes interrupted shipments of paper which called for economy of use and efficient stockpiling, the real problem was the «appropriation» of paper by workers and wastage through unskilled rolling. 'The solution was to exercise greater control by making the cigarette rollers prepare their paper at work, as their first task each morning.

Following the posting of new orders in the Mexico City inanufactory which decreed that workers were no longer per-

70 For a discussion of the idea of space was a strategic element in games of power, as a stake in social struggles» see Perrot, Michelle: «On the Formation of the French», pays. 33.84. 
mitted to take paper home at night, petitions were submitted, in the usual manner by cigarette rollers, to protest the order. Denial of their request to suspend the reform provoked a radical reaction. Some cigarette rollers placed posters on the manufactory walls which appealed to their co-workers not to $3 \mathrm{c}$ to work the following day. On the morning of Monday 13 January, 1794, an estimated crowd of 1,400 workers, women and men (approximately one-quarter of the cigarette roilers) marched on the viceregal palace shouting and demanding repeal of the order. Witnesses later testified that strikers stood in front of the manufactory and pelted them with stones as they passed by them to go to work ${ }^{71}$. Troops were ordered to dispel the crowds and make them return to work in the manufactory. By 10.30 a.m. everybody, reportedly, had returned to work ${ }^{T 2}$. Once again, representatives in the «name of the workers» (both men and women) petitioned for the revocalion of the order. They argued that the preparation of paper was simple but arduous and a worker could not roll and twist In the same day without damaging his fingers and shoulders. Preparation at home with the help of family members took anywhere from half an hour to a couple of hours. The representatives conceded that theft and substitution of poor for high quality monopoly paper occurred, but that it was actually riot a very advantageous practice because poor quality paper could not be worked easily and quickly and jeopardized completion of a tarea ${ }^{78}$.

Assessments were made as to the long term effects of the new work order on both workers and manufactory production. The manufactory administrator argued that in the long term the rate of production would decline and the quality of products would worsen. Preparation of paper at the beginning of each day placed and excessive burden on the workers. The workers,

71 AGN, Tabaco 376, director-general to viceroy Revillagigedo, 29 January 1794.

72 AGI, Mexico 2.285, viceroy Revillagigedo to Gardoqui, 3 February 1794.

73 AGN, Tabaco 376. Andrés Fuentes, José María Soria, José Rodrigo Rosón, operarios, to viceroy Revillagigedo; AGN, Tabaco 376, Hierro to Revillagigedo, 16 January 1794. 
in the attempt to complete their tareas despite the extra work, would become exhausted and ill ${ }^{74}$. As a result of the investigation the reform was quickly abolished. By 26 January 1794 , two weeks after the riot, preparation of paper in worlkers' homes was in practice once more. The workers' representatives responded by proclaiming their gratitude to the King such that «only with silence can we thank you. There is no other language more meaningful for a prince as perfect as your excellency» ${ }^{75}$.

The organization of the Paper Riot demonstrates the capacity of the workers to act collectively, if not unanimously. Its resolution reveals again, the state's concessions to worker demands but, at the same time, to take action designed to remove the possibility of such collective protest happening again ${ }^{76}$. Workers' testimonies gathered during an investigation of the Paper Riot illustrate how the organization of the strike was carried out and supported by associations outside of, as well as inside the manufactory, and the strength of local intelligence networks. Workers repeatedly referred to conversations and petition gathering which took place in the barrios close to the manufactory, in the pulquerías, in the churches, even in local hospitals where it was an ailing worker who unwittingly revealed the protesters' plans. But why did some workers believe themselves justified in their strike action against the monopoly? The participants and instigators of the strike, as, far as I can ascertain, were all cigarette rollers, men and women, and made up one quarter of the total number of cigarette workers. Other than these general characteristics,

74 AGN, Tabaco 376, Puchet to director-general, 17 January 1794.

75 AGN, Tabaco 376, letter signed by Fuentes, Rozon and Soria, and passed by the administrator to the director-general. Also see letter from director-general to viceroy Revillagigedo, 29 January 1794.

76 The early 1790s were particularly sensitive years for the Bourbons both domestically and in its Spanish colonies. In 1792, considerable attention was paid to reports of public disturbances which protested against the tobacco monopolies in the Philippines and Venezuela. The colonial state considered the idea of abolishing the monopolies throughout Spanish America, although nothing came of such deliberations. See Barbier, Jacques A.: The Culmination of the Bourbon Reforms, 1787-1792, «Hispanic American Historical Review», 57, 1977, pars. 67. 
there is no information on the individual backgrounds of the participants, so we cannot know if they possessed other cha1acteristics in common, if they were recently employed, if they were migrants, and so on. I would speculate that they probably represented workers who were most recently employed, and therefore, earning the lowest piecework rates, and who probably comprised a floating part of the workforce, and who worked only sporadically. But this is pure conjecture based on theories put forth by historians of the laboring classes of eighteenth century France who argue that «militant activity is perhaps inversely proportional to the organic cohesion of the trade, the strength of the organization, and the ideology of the group...the highest level of militancy existed among the poor relations, those trades that were a crossroads or a catchall; ...A strong militant identity among workers in a craft seems to imply a weak collective professional identity and vice versa» ${ }^{77}$. Such a construction is possible given the variation within the manufactory workforce, but without a better sense of the strikers' general characteristics, it is impossible to make a compelling argument one way or the other. There is little (doubt, however, that the protesters were provoked by a reform which threatened their livelihoods and their living standards and which would remove not only the flexibility of time which preparation at home gave to them, but access to a commodity which was used to supplement their income. It may even be that the Concordia reform which demanded a certain commitment from the workers in terms of time spent in the manufactory if they were to reap its benefits, affected their perception of monopoly employment. What their actions demonstrate above all, is some form of a plebian moral economy in action.

Workers' testimonies convey again the divisions within the workforce. It was several supervisors and guards who in-

77 Rancière, Jacques: "The Myth of the Artisan: Critical Reflections on a Category of Social Historyw. In Work in France - Representations, Meaning, Organization, and Practice, Steven L. Kaplan et al., eds., Ithaca, 1986. 
formed the administrator of the impending strike and protest, after their accidental discovery of the plan. What this reflects, at its simplest, is that not only did the reform not affect them directly, since they received fixed daily wages, out that they preferred their jobs to protest, and felt no fear of retribution from the workers.

The Paper Riot of 1794 confirmed the colonial state's worst fears. At the same time, it laid bare the contradictions of Bourbon state-building, and the sometimes tenuous compatibility between social stability and economic prosperity. The ministers of the Royal Court of Audit denied that the workers constituted a political threat to Mexico City, primarily to avoid complaints from the colonial elite or pressure to elimi1 ate one of the most lucrative and stable sources of government income. They described the tobacco workers as:

possessed of a timid and submissive spirit which makes them obedient and quick to carry out any orders, specially when aided by the troops which they naturally respect 78 .

Such soothing rhetoric, however, did not prevent a rapid move to rationalize and reduce the number of workers in the Mexico City manufactory in order to exert greater control. One of the solutions was a to employ only women in the manufactories, particularly as cigarette rollers, a task which was becoming increasingly identified as a «female» occupation. The policy was put into practice. In 1795, women comprised 43 per cent of the Mexico City manufactory workforce $(3,055)$; by 1810 , their percentage share increased to an estimated 71 per cent $(3,883)$, which, although there was a reduction in the Mexico City workforce, the percentage share still represented an absolute increase in the number of women employed ${ }^{7 y}$.

78 AGN, Tabaco, 241, Real Tribunal y Audiencia de la Contaduría Mayor de Cuentas de Mexico, 9 March 1796.

79 Overall, the total number of manufactory workers (including supervisory workers and bureaucrats) increased from an estimated 12,013 in 1795 to 13,316 in 1809. In 1795, 54 per cent of the total work force was female; by 1809 that percentage had increased to 68 per cent. These figures are based on a variety of reports for the individual manufactories in various 
In all likelihood, after a few months of the new system, with of without worker protest, the old method of paper preparation would undoubtedly have been reestablished to avoid a fall in cigarette production. The important considerations here, however, are first, that the resolution was ostensibly in the workers' favor which affirmed the justice of the procedure of investigation, and resolved the uncertainties created by the intended reforms. Second, the colonial state remained unwilling to undertake economic innovations at the price of social peace. After 1794, no further attempts were made by the Bourbon administrators to implement reforms in the organization of production in the manufactories, and no further strikes or collective action of the magnitude exhibited in 1794 was reported. Petitions, negotiations, shouting matches, and «down tooling» continued apace as part of the daily negotiation.

These two examples of state-worker conflict illustrate the problems which confronted monopoly management. The state was confronted by a paradox whereby associations created to maintain loyalty to, and dependence upon the monopoly, could be used to challenge the state's mandates. As a result, to reestablish peace, it acted in a concessionary manner, but attempted, at the same time, to turn such concessions to the monopoly's advantage. Both resulted in compromise soiutions which, on the one hand, may have increased the state's control over the workers, but which, on the other hand, satisfied to some degree the demands made by the workers.

A final brief comment here about what the workers' actions and discourse (what little there is of it) suggest about their beliefs. The workers betray all the hallmarks of operating

\footnotetext{
years taken from the ramo de Tabaco, ramo de la Renta de Tabaco, Indiferente General in the AGN, from the Archivo Histórico de Hacienda, from the Audiencia de Mexico sección in the AGI, from the Archivo Notarial de Orizaba, and from statistics collected by McWatters: The Royal Tobacco Monopoly... For a further discussion of sources and interpretation see DeansSmith, chapter 5, «The Tobacco Manufactories: Rationale, Organization, and Production», in Bureaucrats, Planters, and Workers: The Making of the Tobacco Monopoly in Bourbon Mexico, 1740-1810 (forth coming University of Texas Press).
} 
within the framework of a moral economy. Their petitions were made according to certain «rights» which they claimed for themselves: the right to respect, the right not to be abused, the right to retain control over time and materials, in short, the right to justice, and, if necessary, the right to ensure it was administered. The workers' discourse by which they expressed such rights, drew from the idiom of popular religion. Relations of power and authority, of right and wrong, of obligation were conceptualized through references to Chisrian behaviour, to biblical analogies which dealt with justice and unequal relations. At the apex of this dimly perceived moral order of the workers was the king, the principal arbiter of justice. The language of the workers is loudest in the documentation which the Paper Riot and Concordia investigation produced. (I might interject here how I perceive the use of language: despite innumerable erudite interpretations of language, one of the most practical was coined by one of the world's outstanding curmudgeons, Ambrose Bierce, who in his Devil's Dictionary, defined language as «The music with which we charm the serpent guarding another's treasure») ${ }^{\mathbf{c}}$.

During the investigation of the Paper Riot of 1794, workers' testimony showed how the concept of being a «good Christian» could be interpreted as a legitimation for defiance as well as of obedience. Miguel Landetegui, for example, a 32 year old creole and cigarette roller, described how, on the evening before the strike of 1794 , he met José Espinosa in a church. Landetegui asked how it was possible for Espinosa to consider himself a good Christian if he would not make it clear to the administrator the damage which the new paper regulations would cause to the workers. On hearing Espinosa's response that a church was no place to discuss such matters, Landetegui responded that his concerns were indeed, for «the greater honour and glory of God» ${ }^{81}$.

80 Bierce, Ambrose: «The Devil's Dictionary», in The Collected Writings of Ambrose Bierce, New Jersey, 1946, pag. 287.

81 AGI, Mexico 2.285, fiscal to viceroy, 13 January 1794. 
During the protracted fight over the Concordia, the workers were careful in their petitions to profess loyalty to, and trust in their king as "a Christian Prince». At the same time, they compared themselves to the Children of Israel who sought freedom from the "oppression» and «tyranny» of their latter lay Egyptians, the manufactory administrator and his crories ${ }^{82}$. Like so many inhabitants of colonial Mexico, the workers showed «little scruple in turning religious sentiment to political account» ${ }^{\$}$. Popular religion remained an effective force in the lives of the tobacco workers as it did for the popular masses in general and a force which the colonial state recognized $^{84}$. The workers' use of a religious idiom enabled them to articulate and defend the legitimacy of their demands while reaffirming their loyalty to their Christian King. The material objectives at the centre of tensions between the colonial state and the workers may be reflected in competing, and possibly increasingly dissonant discourses in late colonial Mexico, of secularism and enlightenment thought on the one hand, and popular religion on the other.

Before I conclude, I would like to add a brief postscript to my analysis of the tobacco workers and the colonial state. 'The Mexican Insurgency of 1810 disrupted the functioning of the Mexico City manufactory. Production became erratic and numbers of workers were laid off. How the tobacco workers responded to the insurgency is poorly documented. What is tantalizing by way of evidence, however, is a description of a ceremony in which the workers of the Guadalupe manufactory participated. On June 61820 , the tobacco workers em-

82 Ibidem, gremio de operarios to Exc. Sr., s.f.

83 Brading: Tridentine Catbolictsm..., pag. 15.

84 Ibidem. Brading argues that there was: alittle decline in popular religion in late eighteenth-century Mexico: ...the long-term process of secularisation and erosion of faith which had undermined the position of the Church in Europe was barely noticeable in Mexico other than at the level of recruitment for the mendicant orders\%, pag. 22. During the workers' protests, the directorate-general requested spiritual stormtroopers as well as military ones, particularly the Dominican fathers to help to calm the workers «as they know this type of people and confess them». AGN, Tabaco, 358, Cosme de Mier y Trespalacios to viceroy Branciforte, 11 September 1797. 
ployed in the manufactory of the Villa de Guadalupe gathered in the main patio facing a portrait of Ferdinand VII and watched while their administrator and supervisors, swore fealty and allegiance to their king and protector and to the Constitution of Cádiz. Reportedly, the solemnity of the ceremony of allegiance at its conclusion provoked «applause and rejoicing» and cries of «Long live the Constitution and the King» by the workers ${ }^{85}$. Despite the turmoil of insurgency, the colonial state continued to rehearse its rituals of authority although as David Cannadine has suggested ceremonial occasions cannot be assumed to represent consensus in a Durkheimian sense. Rather, what the ceremonies may celebrate is not simply consensus but the resolution of particular conflicts or reassurance during times of instability, uncertainty, and adjustment to changing circumstances ${ }^{*}$. The question which the example of such a ceremony raises is how the negotiations which structured the social and political relations between the workers and the colonial state affected the reordering of such relations after the abolition of the Spanish monarchy, and the construction of an independent Mexico.

So, what conclusions may be drawn from the above anaiysis of state-worker relations in late Bourbon Mexico? First, the role of the state is clear in its attempts to create paternaiist and co-optive relations with the tobacco workers and to provide institutions which chanelled grievance and conflict. At the same time, the structure of the manufactories contributed to the capacity of the workers to resist unacceptable reforms through newly created corporate bodies. Second, the Mexican tobacco workers showed resilience in the face of state

85 AGN, Fondo Real Hacienda, Caja 94, Acta de juramento que de la Constitución Política de la Monarqula Española sancionada por las Cortes generales y extraordinarias en el año 1812 hicieron en 6 de junio de 1820 los empleados en la fábrica de cigarros de la Villa Nuestra Senota de Guadalupe.

86 Hammerton, Elizabeth and Cannadine, David: Conflict and Consensus on a Ceremonial Occasion: The Diamond Jubilee in Cambridge in 1897, «The Historical Journal», 24, 1, 1981, pags. 111-146. Also see Wuthnow, Robert: Meaning and Moral Order-Exploratio:is in Cultural Analysis, Berkeley, 1987. 
reform. Although the colonial state increased its control over workers' actions, they proved able to defend their interests, to negotiate for that «better bargain» and in the process, contributed to the limitations of both monopoly development and the powers of the colonial state. The workers remained, nevertheless, fragmented and retained an abiding faith in the king as a solution to, rather than as a part of, the problems they experienced.

Susan Deans-Smith 